\title{
Empowerment of Micro, Small, Medium Enterprise (MSME) Using SWOT Analysis
}

\author{
Sudjilah $^{1^{*}} \quad$ Eny Rachmawati ${ }^{2}$ \\ 1.Sekolah Tinggi Ilmu Ekonomi Indonesia Malang. Jl. Megamendung 1-9 Malang \\ 2.Universitas Mayjen. Sungkono Mojokerto. Jl. Irian Jaya No. 4 Mojokerto 61321*
}

\begin{abstract}
MSMe (Micro, Small, and Medium Enterprises) become a vessel proven quite productive in reducing unemployments. This labor-intensive business does not require specific prerequisites i.e. education level, employee expertise with relatively-low business capital requirement, and simple technology uses. This sector holds crucial roles in the improvement of gross domestic product (GDP) for Indonesian economy. This study aimed to identify, analyze, and describe the growth of MSMe in Malang City. As an explorative study with descriptivequalitative approach using SWOT analysis tool, this study found - based on SWOT analysis developed into IFASEFAS matrices, TOWS matrix, and SWOT Cartesian Diagram - the most suitable strategy is the S-T Strategy located on the quadrant IV of the diagram. This is a strategy that employs strength factors to overcome threat factors. Therefore, the strategy implementation is through improvements of MSMe's products in order to compete with products in other places by continuously innovating unique product advantages.
\end{abstract}

Keywords: MSMe Empowerment, Creative Economy, SWOT Analysis

DOI: $10.7176 / \mathrm{EJBM} / 13-8-07$

Publication date: April $30^{\text {th }} 2021$

\section{Introduction}

Within the globalization context, competitiveness is the main key of success and survival. This manner is not only taken as creating products in large quantities, but also bearing in mind their qualities. The quality of these products can be achieved through establishing an image/brand or creating innovative products unlike other regions. High level of creativity is needed to enable the production of innovative products. Built upon this premise, creative economy finds its existence and thus develops. (Salman, 2010)

Creative economy has been developed in numerous countries and has presented positive and significant results, for instance employments, increase in regional revenue, and place branding in national and international scale. Place branding emerges when that region becomes widely known due to creative products that they produce. This can also be seen in Malang City which is now famed for its meatball (bakso), traditional masks (Topeng Malangan), and religious tourisms, local football league (Arema) t-shirts and Arema-labeled products, and so on. Further refinements are needed for the optimization of its place branding through creative economy which intertwines various sectors, among which is tourism. Undoubtedly, creativity is an essential capital in dealing with global challenges.

All types of creative economy are always presented with their own unique added values, creation of their own market, and their ability to absorb labors with economic income. The Indonesian Department of Commerce utilizes this momentum by formulating the 2009 - 2015 Creative Economy Development Plan. Indonesian Department of Commerce (2008) devised the creative economy as an attempt to achieve sustainable economic developments through creativities with competitive economic climate and renewable resource reserves. Developing creative economy requires competent human resources with high innovative and creativity ability. In addition to the need for quality human resources, achieving creative economy also calls for spaces or vessels in which they can seek ideas, hustle, while also fulfilling their self-actualization needs and creative thoughts. In developed countries, the provision of creative spaces leads to creative cities based on conducive atmospheres for communities, therefore accommodating creativity to flourish. Cities in Indonesia - along with their unique attributes - have the potentials to be developed as a creative city. This has been addressed by the Ministry of National Development Plan/National Development Planning Agency (2014) which stated that the Development Plan consists of 22 Small and Medium Industry Centers (SIKIM; Sentra Industri Kecil dan Menengah) comprising 11 in the Eastern Region of Indonesia (especially in Papua, West Papua, Maluku, West Nusa Tenggara, and East Nusa Tenggara) and 11 in the Western Region of Indonesia. The establishment of creative economy will influence growth and development. As a facilitator, the government requires entrepreneurial mental attitudes, so that throughout the implementation of their workss and function, they are no longer oriented to cultural centralization, structuralization, formalization, and apathy, but instead to be aligned towards innovation, boldness and creativity, value-creating ability, identifying opportunity, communication skill, and mobility of human and organization resources (Rusydiana and Abrista, 2017). Developments should involve all layers of society with the aim of realizing a just and prosperous population. A development may rely on Micro, Small, and Medium Enterprise (MSMe; Usaha Mikro Kecil dan Menengah) (Adiningsih, 2008 in Muhammad Syukri, 2011). 
Nowadays, the journey of an enterprise faces environmental changes. Changes in business environment are an extremely unpredictable circumstance in future times. MSMe can not be separated from the varying inconstancies. These changes can come from their internal or external environments. Changes in environment can have negative influences which may interrupt MSMe and positive influences which will help them to sustain and thrive in the course of MSMe empowerment. When facing changes in their environment, SWOT analysis is divided into two steps, which are the Internal Environment by identifying the strengths and weaknesses of an MSMe. External Environment, by finding out the threats and opportunities faced by an MSMe. The use of SWOT analysis can be a guide for discovering the various internal and external factors which may be used as a guideline for MSMes to develop themselves according to demands of changes that may happen.

Research that utilized SWOT analysis presents the following result. Arif Rahmana, Yani Iriani, and Rienna Oktarina (2012), with S-T strategy, which worked with strengths in order to overcome threats to increase the competitive edge of MSMe. In addition, research by Chusnul Chotimah (2017) covering Strength factor of MSMe, which are: Guaranteed products' quality, accessible raw materials, assortment of products, affordable prices, and ultimately the Village's superior product. Meanwhile, Weakness factors of MSMe are: Limitations of operational capitals, marketing not maximized. External factors, which is Opportunity factor consisting of: Adequate level of labor availability, participation in entrepreneurial seminars, promotions, seasonal demands, high consumer interest; Threat factors consisting of: Fierce competitions, instability of raw material's price, and the appearance of more innovative similar products. Pratiwi Anggraeni and M. Kholid Mawardi (2017) with their research results pointing out that: Strength factor: Quality product, variants of flavors, healthy relationships between the owner and the employees, and its retailer. Weakness factor: Lack of labor and conventional financial management. Opportunity factor: The government's concern displayed by their providing People's Business Loans (KPR; Kredit Usaha Rakyat) and on-site visits, available raw materials, and Malang City as a tourist destination. Threat factors: high competitiveness of similar MSMes, unstable economic conditions, intense competition of gift shop's online marketing. The results of research are in Diversification or the S-T strategy, which utilizes strength to overcome various kinds of threats. The proper strategy is (1) to increase the quality of products, by creating unique product innovations. Moreover, research by Ronda Deli Sianturi (2020). There are 4 strategies: The S-O Strategy, where the MSMe creates innovations, establishing unique characteristics on their products while also employing technology as a media for promotions and sales; The W-O Strategy, which observes the market share desires and thus the economic actor continues to innovate; The S-T Strategy, where the products have distinct characteristic values and give their own trademark protection; The W-T Strategy, which introduces products outside the clusterization and the product is packaged innovatively. Titik Inayati, Evianah, Hendra Prasetya (2020) found that the result value of strengths is greater than that of weakness. EFAS matrix shows value above the internal factors. Opportunities were greater than threats. The highest score on the Strength-Opportunities (S-O) Strategy, StrengthsThreats (S-T) Strategy, Weaknesses-Opportunities (W-O) Strategy, and Weaknesses-Threats (W-T) Strategy, which showed that $\mathrm{S}-\mathrm{O}$ was leading. 4. IE analysis is an analysis for the growth and development period of a business. This strategy which can be applied is the Strengths-Opportunities Strategy by maximizing the strengths available while also paying close attention to market opportunities.

\section{Methods}

This study was descriptive-qualitative explorative research. Primary data were sourced from 81 informants and collected through purposive sampling method while secondary data were obtained from literatures and journals. The author resorted to in-depth and interactive data collection (Miles and Hubberman in Sugiyono: 2014) where the author personally blended with the respondents. This was done during the process of data collection, data display, data reduction, and conclusion drawing. The validity of data was made sure using triangulation method (Moleong, 2013), by comparing observation result data with interview results, perspectives of the interviewees using real data in the field, and interview results in the supporting documents. Data collection methods were through interviews and documentations using guided questionnaire instrument. Analysis tool used SWOT Analysis, which was developed into IFAS-EFAS, TOWS Matrix, and SWOT Cartesian Diagram.

\section{Result and Discussion}

The empowerment of Micro, Small, and Medium Enterprises aims to grow and develop their businesses in order to achieve national economy based on equitable economic democracy. This can be achieved when MSMs are enabled to grow. Empowerment is the synergic efforts by the Government, Local Government, Business World, and the society in the growth of business climate and development for MSMe so that they may expand and evolve to become resilient and independent businesses (The Act No. 20 of 2008 Article 1 Section 8). The principles of empowerment are: a. Growth towards self-reliance, togetherness, and entrepreneurship of MSMe for honing one's own expertise, b. Embodiment of transparent, accountable, and just public policies, c. Development of localpotential-oriented and market-oriented businesses in accordance with MSMe's competence, d. Improvements of MSMe's competitiveness, and e. Establishment of integration among plan, implementation, and management. 
(Tambunan: 2012)

MSMe (Micro, Small, and Medium Enterprise). According to The Act No. 20 of 2008, the term "SMe" (Small and Medium Enterprise) was expanded to "MSMe" (Micro, Small, and Medium Enterprise. Micro Enterprises are enterprises which have an asset (excluding lands and buildings) of maximum Rupiah 50.000.000,- with annual revenue of maximum Rupiah 300.000.000,-. Small Enterprises are enterprises which have an asset (excluding lands and buildings) of between Rupiah 50.000.000,- and Rupiah 500.000.000,- with annual revenue of between Rupiah 300.000.000,- and Rp 2.500.000.000,-. Medium Enterprises are enterprises which have an asset (excluding lands and buildings) of between Rupiah 500.000.000,- and Rupiah 10.000.000.000,- with annual revenue between Rupiah 2.500.000.000,- and Rupiah 50.000.000.000,-

According to Rahmana 2009 (in Pratiwi and Kholid (2017), SMe can be classified into 4 groups based on their development perspectives: a. Livelihood Activity, a SMe that is used as a working opportunity to earn a living, known as an informal factor, e.g. street hawkers. b. Micro Enterprise, an SMe that has craftmanship natures but lacking in entrepreneurial skills. c. Small Dynamic Enterprise, a SMe that has both entrepreneurial skills and the ability to accept subcontracting and exports. d. Fast Moving Enterprise, a SMe that has entrepreneurial skills and will undergo transformations to become Big Businesses (UB; Usaha Besar).

MSMe has distinct characteristics in terms of its market orientation, enterprise owner's profile, nature of work opportunities within the enterprise, established organizational and management system, mechanism degree in production processes, capital and raw material sources, activity location, external relationships, and degree of women involvement as business actors. As addressed by Urata in Malano (2011), the role of SMe can at least be seen from: Its position as the main actor of economic activities in various sectors; provider of some of the largest employments; profound figure in the development of local economic activities and community empowerment; creator of new markets and innovation sources. In its development, the MSMe sector suffered from fluctuations, despite facing the 1997/1998 financial crisis, this sector became the saviour of Indonesian economy. These fluctuations were caused by the existence of obstacles throughout its growth which may vary between one region and another. The mentioned obstacles may be: capital restraints, marketing difficulties, technological limitations, and human resource competence. Undoubtedly, these obstacles should not be left as stumbling blocks in the empowerment of MSMe. The reduction of these obstacles may be by mapping MSMe positions to determine their strategies and main strategy which may then be developed. This study conducted SWOT analysis, an analysis that observes and analyzes internal factors (strengths and weaknesses) and external factors (opportunities and threats).

In general, Creative-Economy-Based MSMe in Malang City is located in Bandulan Sub-District, on Raya Bandulan Road on the west of Amprong Bridge which ends at the Tebo Utara T-junction. The location is packed with MSMe business sectors with a total of 81 stalls/venues. In regard to the business sectors, the author limits this study's scope to only covering on the culinary sector - a creative industry dominantly occupying the venues in the studied location. This is based on the people's life style that seeks culinary adventure. This region is wellknown due to openings of new residential areas, dwellers who mostly work outside their hose, buildings that are used as boarding houses, women who are largely career woman. Phenomena such as these become an opportunity for culinary businesses to thrive. Various menus are served in this area, such as Chinese foods that have merged with Indonesian local wisdom, mixed tofu soup (tahu campur), lamb/chicken satay, wonton noodles (pangsit mie), meatball soup (bakso), sayur lodeh, ayam geprek sambal bawang, chicken rice and duck rice (nasi lalapan ayam dan bebek), fried rice (nasi goreng), fried tapioca balls (cilok), wet krupuk in spicy sauce (seblak), Turkish kebab, Javanese fried rice, toasts, murtabak, Padang steamed rice dish (Nasi Padang), Hisanna (Indonesian adaptation of KFC), traditional Indonesian soup (Soto), Pawon Emak, Indonesian hamburger/hotdog, ginger honey egg milk beverage $(S T M J)$, various shaved ice desserts, and so on. This study was conducted through the collection of data and information as complete as possible related to Indonesian-prepared cuisines, so that they can be published through suitable media in order to benefit from any possible opportunities. Not to mention the digital era in which most MSMe actors have been using mobile application to increase their revenue, for instance GoFood, GoSend, etc. No less important are the local television media which may also prove to be beneficial for promotions. Like any other culinary tourism in general, the assortment of cuisines in the Raya Bandulan Road in Malang offers unique dishes which are not commonly found on other places in Indonesia. According to Pak Rokhim, "The cuisines in Malang usually have a place in the consumer's heart, such as when people from cities outside of Malang who come to this city just to buy the mixed vegetable salad in peanut sauce (gado-gado) made by Pak Rokhim, "EDAN" wonton noodles, "NAYAMUL" spicy eggplant dish, "GARUDA" meatball soup, traditional fruit cocktail (Es Teler), Tebo Kikil Rojak jumbo-sized, and others. This is because each stall has its own unique name with its own diverse menu and specialties. The majority these culinary stalls leave a memorable experience in the heart of their customers. This appeal indirectly becomes a crucial component of a place's identity, especially when connected to the regional tourism sector.

The research found that the culinary business was facing two factors, which are the internal and external factors. Each factor should be identified so that suitable strategies can be employed to maximize its strength factors while also minimalizing its weaknesses. The followings are tables on internal and external factors 
Table 1. Internal and External Factors of Culinary Industries in Malang No. Internal Factors

Strength

1. Products are suitable for sale according to the targeted market segment

2. Products have various flavors and price ranges according to the targeted consumers' choice and ability.

3. Harmonious relationship berween the owner and the employees due to the industry being a family-driven business.

4. Cordial relationship between supplier retailer due to emotional closeness between them. Weakness

1. Limitations of labor that affects work efficiency if one or more employee is not present.

2. Conventional financial management, meaning that it is likely that they may not separate business capital with personal needs.

No. External Factors

Opportunity

1. The Government as a facilitator have facilitated the place and capitals of People's Business Loans for MSMe with supple nature conforming to the mandate from The Act related to MSMe in 2008.

The Government has provided a permit for the studied region as an industrial as well as a residential area which

2. enables the empowerment of culinary businesses so that they may have greater chance. Moreover, most people

in the neighborhood are newcomers who work outside their house which made them often order food for takeaways.

3. Raw materials that are always available and accessible in close proximity due to adequate facilities and infrastructures.

4. Malang City is a tourist destination for both domestic and foreign visitors.

\section{Threat}

1. Fierce competitiveness among creative industries, particularly culinary industries, in the Bandulan region.

2. Fluctuating tendencies of raw and indirect materials due to uncertain season factors which may influence products' demands and supply. Meanwhile, the sellers do not care as much about factory supply planning.

3. Online sale competitions (GoFood/GoSend) will have an impact towards those who lack the grasps on technological advancements.

Source: Analyzed research result, 2020.

Next, IFAS and EFAS analyses were conducted to determine the main strategy in the optimization of MSMe empowerment. IFAS-EFAS matrices are used in SWOT analysis for data analysis. The analysis in this study covers analyses on internal and external factors that contribute ot the empowerment of MSMe. Internal factors employ IFAS (Internal Factor Analysis Summary) table, while the external factors employ EFAS (External Factor Analysis Summary) table. Both of which can be seen on Table 2.

Table 2. IFAS and EFAS analysis

\begin{tabular}{|c|c|c|c|c|}
\hline Internal Factors & \multicolumn{2}{|c|}{ Weight Rating } & Score & Details \\
\hline \multicolumn{5}{|c|}{ Strengths } \\
\hline $\begin{array}{l}\text { S1 } \\
\text { Products are suitable for sale according to the } \\
\text { targeted market segment. }\end{array}$ & 0,20 & 5 & 1,00 & $\begin{array}{l}\text { Packaging and flavour variants can be } \\
\text { adjusted according to the order and } \\
\text { consumption time. }\end{array}$ \\
\hline $\begin{array}{l}\text { S2 } \\
\text { Products have various flavors and price ranges } \\
\text { according to the targeted consumers' choice and } \\
\text { ability. }\end{array}$ & 0,20 & 5 & 1,00 & $\begin{array}{l}\text { Various flavour options the consumers } \\
\text { want can be catered according to the } \\
\text { palate and identity of Malang. }\end{array}$ \\
\hline $\begin{array}{l}\text { S3 } \\
\text { Harmonious relationship berween the owner } \\
\text { and the employees due to the industry being a } \\
\text { family-driven business. }\end{array}$ & 0,15 & 4 & 0,60 & $\begin{array}{l}\text { Strong emotional bonds and } \\
\text { togetherness are forged among them, } \\
\text { i.e. high sense of belonging. }\end{array}$ \\
\hline \begin{tabular}{|l|}
$\mathrm{S} 4$ \\
Cordial relationship between supplier retailer \\
due to emotional closeness between them.
\end{tabular} & 0,20 & 5 & 1,00 & $\begin{array}{l}\text { Loyalty are formed among people } \\
\text { sharing the same fate and circumstance } \\
\text { as the common class (wong cilik). }\end{array}$ \\
\hline Sub-Total: & $\mathbf{0 , 7 5}$ & & 3,60 & \\
\hline \multicolumn{5}{|l|}{ Weaknesses } \\
\hline $\begin{array}{l}\text { W1 } \\
\text { Limitations of labor that affects work efficiency } \\
\text { if one or more employee is not present. }\end{array}$ & 0,10 & 1 & 0,10 & $\begin{array}{l}\text { Limited number of workforces affects } \\
\text { work completion and consumer service } \\
\text { experience. }\end{array}$ \\
\hline
\end{tabular}




\begin{tabular}{|c|c|c|c|c|}
\hline Internal Factors & Weight & Rating & Score & Details \\
\hline $\begin{array}{l}\text { W2 } \\
\text { Conventional financial management, meaning } \\
\text { that it is likely that they may not separate } \\
\text { business capital with personal needs. }\end{array}$ & 0,15 & 3 & 0,45 & $\begin{array}{l}\text { Occasionally, capitals are used to } \\
\text { cover personal expenses, such as a } \\
\text { child's tuition fees, festivities, } \\
\text { buwuhan (traditional event), Family } \\
\text { Welfare social gathering, etc. }\end{array}$ \\
\hline Sub-Total: & 0,25 & & 0,55 & \\
\hline Total Score: & $\mathbf{1 , 0 0}$ & & 4,15 & \\
\hline
\end{tabular}

Source: Analyzed research result, 2020.

Referring to Table 2, the highest value score belongs to three items, which are suitable products (S1), products with varying flavours with flexible price (S2), and harmonious relationship between the owner and rhe employees (S3), all of which have the same weight and rating of 0,20 and 5, respectively. These three items become the strengths. These findings are analogous with what was addressed by Daniel Marco-Stefan Kleber (2018) who stated that value proposition is about the needs and demands by final consumers and is based on their experience. The author perceives and relates this as the fulfillment of consumer's final need which is about the quality of a culinary product.

The finding answers that there is a possibility of the enterprise's sustainability and development in future times. IFAS Matrix displayed a number of weaknesses. Its weakness factors lie at the financial management with weight of 0,13 and rating of 3 . Weakness become a burden in expanding a business. Analysis results of the IFAS Matrix which comprise all internal factors (strengths and weaknesses) shows a score of 4,15 which means that the culinary business has significant influence which can be made use as the basis for the enterprise's sustainability. External environment analysis employed EFAS (External Factor Analysis Summary) table which can be seen on the Table 3 below:

Table 3. EFAS Matrix for the Culinary Business at Bandulan, Malang

\begin{tabular}{|c|c|c|c|c|}
\hline Opportunities & Weigh & atio & Score & Details \\
\hline \multicolumn{5}{|c|}{ External Factors } \\
\hline $\begin{array}{l}\text { O1 } \\
\text { The Government as a facilitator have facilitated the place } \\
\text { and the capital of People's Business Loans for MSMe } \\
\text { with supple nature according to the mandate from The } \\
\text { Act related to MSMe in } 2008 \text {. }\end{array}$ & 0,10 & 1 & 0,10 & $\begin{array}{l}\text { Facilities for location and soft loans } \\
\text { are in the form of People's } \\
\text { Business Loans (KUR; Kredit } \\
\text { Usaha Rakyat) }\end{array}$ \\
\hline $\begin{array}{l}\text { O2 } \\
\text { The Government has provided a permit for the studied } \\
\text { region as an industrial as well as a residential area which } \\
\text { enables the empowerment of culinary businesses so that } \\
\text { they may have greater chance. Moveover, most people in } \\
\text { the neighborhood are newcomers who work outside their } \\
\text { house which made them often order food for takeaways. }\end{array}$ & 0,05 & 1 & 0,05 & $\begin{array}{l}\text { Ease in obtaining permissions for } \\
\text { holding a bazaar in certain places } \\
\text { which simultaneously become a } \\
\text { culinary tourism. }\end{array}$ \\
\hline $\begin{array}{l}\text { O3 } \\
\text { Raw materials that are always available and accessible in } \\
\text { close proximity due to adequate facilities and } \\
\text { infrastructures. }\end{array}$ & 0,20 & 5 & 1,00 & $\begin{array}{l}\text { Raw materials can be procured } \\
\text { from vegetable seller vendors and } \\
\text { other needs by opening stalls } \\
\text { adjacent to culinary areas with } \\
\text { flexible payment methods. }\end{array}$ \\
\hline $\begin{array}{l}\text { O4 } \\
\text { Malang City is a tourist destination for both domestic and } \\
\text { foreign visitors. }\end{array}$ & 0,20 & 4 & 0,80 & $\begin{array}{l}\text { Tourists who visit Malang City } \\
\text { always bring back cuisines typical } \\
\text { to Malang, such as bakso, rujak } \\
\text { kikil, pangsit mie, etc. }\end{array}$ \\
\hline Sub-Total: & $\mathbf{0 , 5 5}$ & & 1,95 & \\
\hline \multicolumn{5}{|l|}{ Threats } \\
\hline \begin{tabular}{|l|} 
T1 \\
Fierce competitiveness among creative industries, \\
particularly culinary industries, in the Bandulan region.
\end{tabular} & 0,35 & 5 & 1,75 & $\begin{array}{l}\text { Many culinary businesses with } \\
\text { similar genres start to appear from } \\
\text { the youths adopting current } \\
\text { innovation. }\end{array}$ \\
\hline $\begin{array}{l}\text { T2 } \\
\text { Fluctuating tendencies of raw and indirect materials due } \\
\text { to uncertain season factors which may influence } \\
\text { products' demands and supply. }\end{array}$ & 0,05 & 3 & 0,15 & $\begin{array}{l}\text { The sellers did not yet understand } \\
\text { enough about the importance of } \\
\text { safety stock management. }\end{array}$ \\
\hline
\end{tabular}




\begin{tabular}{|l|l|l|l|l|}
\hline \multicolumn{1}{|c|}{ Opportunities } & Weight| & Rating & Score & \multicolumn{1}{|c|}{ Details } \\
\hline $\begin{array}{l}\text { T3 } \\
\text { Online sale competitions (GoFood/GoSend) will have an } \\
\text { impact towards those who lack the grasps on }\end{array}$ & 0,05 & 4 & 0,20 & $\begin{array}{l}\text { Other culinary businesses in } \\
\text { Malang City resort to internet as } \\
\text { sales and purchase transactions } \\
\text { media. Only a handful proportion } \\
\text { in Bandulan area were able to make } \\
\text { use of IT innovations }\end{array}$ \\
\hline Sub Total: & $\mathbf{0 , 4 5}$ & & $\mathbf{2 , 1 0}$ & \\
\hline Total Skor: & $\mathbf{1 , 0 0}$ & & $\mathbf{4 , 0 5}$ & \\
\hline
\end{tabular}

Source: Analyzed research result, 2020.

Referring to Table 3, the external main factor which has the highest opportunity score is raw material (O3) with weight of 0,20 and rating of 5. EFAS Matrix presents a main threat factor of high competitiveness of culinary creative industries with weight of 0,35 and 5 rating score which sums up to 1,75 . This threat is caused by the multitude of similar culinary businesses that emerges as an initiative by the youths through contemporary innovations and creativities. This factor has an impact on the attempts of optimizing the empowerment of culinary creative industry in the study location.

Analysis on EFAS Matrix result consists of external factors (opportunities and threats), with a score of 4,05 proving that culinary business in the study location has substantial opportunities while also potentially facing tremendous threats. Reflecting on these results, the sellers must be able to develop their business using constant innovations and creative approaches in order to stay competitive. Dynamic thinking, e.g. design thinking, is essential to create values for customers in order to guarantee their sustainable adaptation of the enterprise's value proposition with customer's needs and demands (Tuominen and Ascenção, 2016).

TOWS Matrix

Referring to the IFAS and EFAS tables, the author then created designs while also devised a formulation for strategic direction by applying the TOWS Matrix developed by Weihrich (Wheelen and Hunger, 2004 in Solihin, 2012). TOWS Matrix can be used as a reference for identifying alternative strategies. Combinations are created for each factor, i.e. S-O (Strengths-Opportunities) Strategy, W-O (Weaknesses-Opportunities) Strategy, S-T (Strengths-Threats) Strategy, and W-T (Weaknesses-Threats) Strategy. S-O Strategy is a business or business unit strategy that accentuates strengths owned to be used as opportunities (Solihin, 2012). S-O Strategy includes: 1. Products suited for sale, meaning that the product's quality is relatively hygienic and is according to consumer's preference and purchasing power. This is especially related to mix marketing which consists of Product, Price, Place, and Promotion. Studies show that the adoption of marketing mix by entrepreneurs will enable them to have a competitive advantage for their competitors (Mukaila \& Adefemi, 2011). Product quality can increase consumer confidence in the company and encourage interest in buying products for consumers. In terms of products, companies must be more active in updating product information (Sari, 2017). Servicescape from the results of this study has a positive and significant influence on consumer purchasing decisions.

It has relatively affordable price for the local market segment, while in terms of location, the place is within proximity due to being positioned near major roads though this means that it lacks the aesthetic value. Promotion is limited to banners ornamented in front of their venue or is sufficiently integrated with the place in which they sell their products. This promotion model is enough to be recognized by consumers. Based on interviews with several respondents, most promotional media uses mouth promotion, i.e. word-of-mouth promotions. Sudjilah and Enny (2018) said that the average number and perception index show that the average consumer perception in each variable is classified as a medium where the advertising and promotion variable reach low values and Word of Mouth (WOM) reaches the biggest score. 2. Products have varying flavours and price ranges. By flavours, it means that there are abundant taste alternatives which the consumers can select according to their own liking, for instance burgers or mie farm, Edan wonton noodles, kikil rojak, kebab, bakso with gradual spiciness level ranging from 1 - 5. In other words, the higher the level, and the spicier the dish will be. The same goes for kikil rojak, with numerous "grades" to choose from. This also applies to EDAN wonton noodles with options of levels up for grabs. 3. Harmonious relationship between the owner and the employees. As self-explanatory as it can be, family has its natural closeness and togetherness connection among its member. This is what makes the business survive; most businesses have operated for more than five years. 4. Cordial relationship between supplier retailers. Their transaction system with the supplier retailer is the "take now, pay tomorrow" system, meaning paying now is a payment for the day before's transaction. This model is what creates such good relationship among them which causes the business to thrive. Not to mention that the supplier is willing to provide delivery services. This forges a mutualism symbiotic relationship among the actors. In addition, business actors can employ GoFood/GoSend/other means for online marketing to promote their products, for example, social media.

S-T Strategy improves the quality of products in order to compete with other culinary businesses while also enhancing the products' innovation and creativity in order to establish unique and distinct characteristics. These distinction — apart from its grade or level— can be seen from the size of products, whether they are small, medium, 
or large which caters every consumer's needs and capacity. W-O Strategy makes use of the credit facility given by the government to increase their capital. The purpose is so that MSMe actors do not utilize funds from money lenders and business location designation. Technological advancements are also adopted even though in its simplest form and purpose, e.g. for improving work management capability. W-T Strategy comprises of maintaining employee's performance in favorable terms by treating them as a business partner and maintaining the use of proper raw materials to preserve product quality.

The next step is that data is displayed using SWOT Cartesian Diagram by referring to the Table 2 of IFAS Matrix. The score of strength factor is 3,60 and the score of weakness factor is 0,55. As for the Table 3 of EFAS Matrix, the score of opportunity factor is 1,95 whereas the threat factor's score is 2,10 . Value difference between strength and weakness factors is (+) 3,05 and between opportunity and threat factors is $(-) 0,15$ due to opportunity factor score being lower than that of threat factor. Identification results of all internal and external factors with their score value differences are then displayed in a SWOT Cartesian Diagram, where the strength and opportunity factors are designated with positive $(+)$ sign and the weakness and threat factors are designated with negative (-) sign. The diagram can be seen on the figure below.

\section{Figure 1. SWOT Cartesian Diagram}

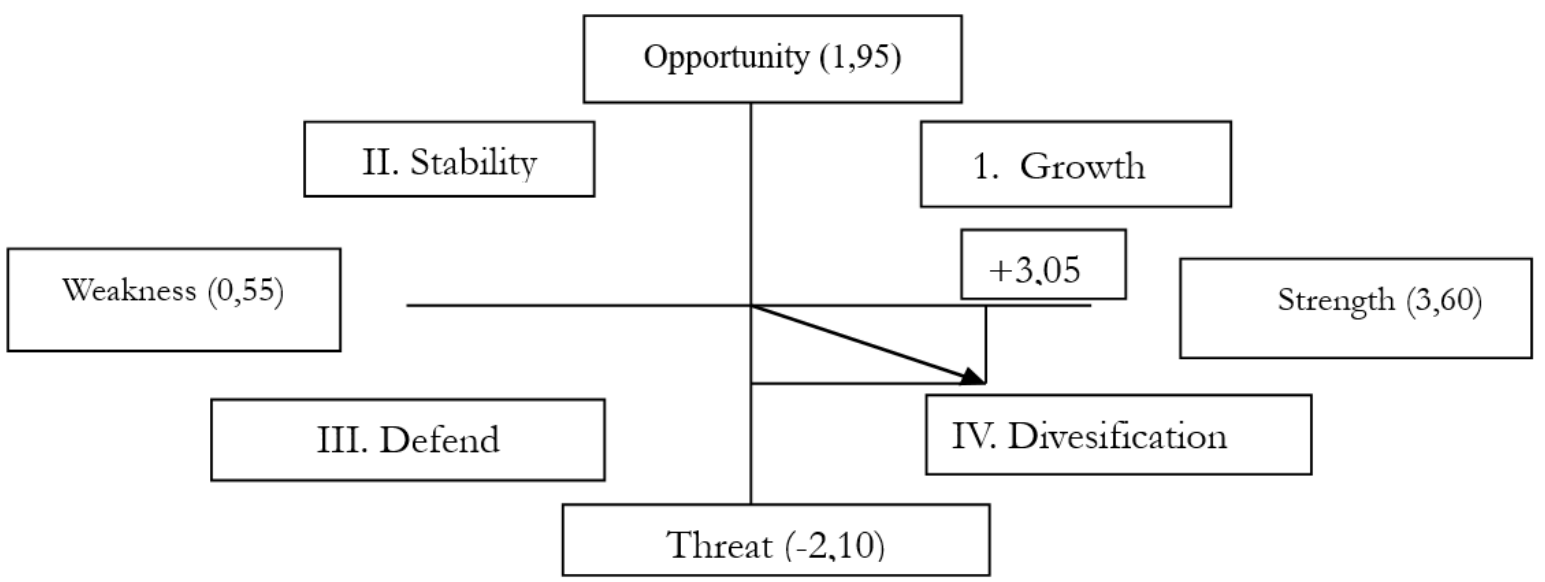

Source: Summary of IFAS and EFAS Analyzed by author, 2020

Next, the picture will then be further elaborated in a table as follows.

Table 4. Combinations of Quantitative Strategy on culinary business in Malang

\begin{tabular}{|c|c|c|}
\hline IFAS & $\begin{array}{c}\text { Strengths } \\
\text { EFAS }\end{array}$ & $\begin{array}{c}\text { Weaknesses } \\
(\mathrm{S})\end{array}$ \\
\hline Opportunities (O) & $\begin{array}{c}\text { S-O Strategy: } \\
=3,60+1,95=5,55\end{array}$ & $\begin{array}{c}\text { W-O Strategy: } \\
=0,55+1,95=2,50\end{array}$ \\
\hline Threats (T) & $\begin{array}{c}\text { S-T Strategy: } \\
=3,60+2,10=5,70\end{array}$ & $\begin{array}{l}\text { W-T Strategy: } \\
=0,55+2,10=2,65\end{array}$ \\
\hline
\end{tabular}

Source: Analyzed Study Result, 2020.

Referring to the SWOT Cartesian diagram on Figure 1, it can be seen that this culinary business is located on the quadrant IV, where the strategy used will be the Strengths-Threats (S-T) Strategy, also known as the Diversification Strategy. Table 4 also indicated that the highest score value is located on the S-T Strategy, which is 5.70 .

Taking into account the analysis results, it is best to impelement the S-T Strategy, i.e. the strategy which takes advantages of strengths to overcome all weaknesses. Strategy implementation is as follows: 1. Improving the product's quality so that it may compete with other culinary business: Raw and indirect materials are always available and provided by the supplier, which in this case, are circulating vegetable sellers close to the business location. Maintaining positive working relationships between the owner and the employees is essential in addition to establishing healthy connection with the business actors and the supplier retailer. Furthermore, continuously making product innovations is crucial to create unique characteristics as its distinguishing features from other similar businesses through the adoption of techonological advancements to improve business' service to consumers. These findings support preceding research findings: Arif Rahmana, et al. (2012), Chusnul Chotimah (2017), Pratiwi Anggraeni and M. Kholid Mawardi (2017), Titik Inayati, Evianah, Hendra Prasetya (2020), and Ronda Deli Sianturi (2020). 


\section{Conclusion}

The results of study utilizing SWOT analysis comprising Strength factors, which are sale-worthy products with varying flavours and price ranges, harmonious relationship between the owner and the employees, cordial relationship with the supplier /retailer; Weakness factors, which are the limitation of labors and conventional financial management; Opportunity factors, which are the facilitator role of the government and permit of establishing a business that empowers culinary creative economy; and Weakness factors, which are tight competitions fluctuating price of raw and indirect materials, and the existence of online sales competitions (GoFood/GoSend). The business is positioned at the quadrant IV (Diversification) with S-T Strategy by employing its strengths to overcome threats. Therefore, it can be concluded that the most suitable strategy to be implemented is through improving product quality in order to compete better while also innovating so that unique and distinct characteristics can be established as a distinguishing feature among existing businesses.

\section{References}

A.Rahmana, Y. Iriani and R. Oktarina, (2012) "Strategi Pengembangan Usaha Kecil Menengah Sektor Industri Pengolahan," Jurnal Teknik Industri, vol. 13 (1), 14-21.

Chusnul Chotimah. (2019). Analisis SWOT Dalam Menentukan Strategi Pemasaran Produk Aneka Keripik Pada UMKM Sekar Arum Sukosewu Gandusari Blitar.Skripsi. Jurusan Ekonomi Syariah Fakultas Ekonomi Dan Bisnis Islam Institut Agama Islam Negeri Tulungagung

Departemen Pedagangan Republik Indonesia (2009-2015).Rencana Pengembangan Ekonomi Kreatif 2009 - 2015. Kemendag.Jakarta

Kementerian Perencanaan Pembangunan Nasional/Badan Perencanaan Pembangunan Nasional (2014).Jakarta.

Kleber, D. M. S. (2018). Design Thinking for Creating an Increased Value Proposition to Improve Customer Experience. Etikonomi: Jurnal Ekonomi. Vol. 17 (2): 265 - 274. doi: http//dx.doi.org/10.15408/etk. v17i2.7311.

Malano, Herman. (2011). Selamatkan Pasar Tradisional: Potret Ekonomi Rakyat Kecil. Jakarta: PT. Gramedia Pustaka Utama.

Moleong, Lexy J. (2013). Metode Penelitian Kualitatif.: Bandung.Penerbit PT. Remaja Rosdakarya Offset.

Mukaila A. A, \& J. Adefemi, B. (2011). Marketing Mix Practice as a Determinant of Entrepreneurial Business Performance. International Journal of Business and Management, 7(1), 205-214.

Nasir, dan Yuslinaini. (2017). Analisis Pemetaan Industri Kreatif Subsektor Kerajinan Serta Dampak Peningkatkan Kesejahteraan Masyarakat di Kabupaten Aceh Besar. Jurnal Ekonomi dan Manajemen Teknologi, 1(1), 2017, 11-17

Pembangunan Pariwisata 2015-2019. Kementerian Perencanaan Pembangunan Nasional/Badan Perencanaan Pembangunan Nasional. Jakarta. Desember 2014.

Rahmana, Arif. A. Ramadhan and F. R. Sofiyah, (2012)."Analisis SWOT Sebagai Landasan Dalam Menentukan Strategi Pemasaran (Studi McDonald's Ring Road)," Media Informasi Manajemen, vol. 1, no. 4, 2013, 14 21.

Rusydiana, Aam Slamet, Abrista Devi. (2017) Development Strategy of Micro-takaful Institutions: Case Study Working Group Indonesia. Etikonomi Journal Volume 16 (2) Oktober 2017. P-ISSN: 1412-8969; E-ISSN: 2461-0771, $265-278$

Salman, Duygu (2010). Rethinking of Cities, Culture and Tourism within a Creative Perspective. PASOS. Vol. 8(3) Special Issue 2010.06-16.

Sari,R.P. (2017). Marketing Mix Implementation in Small Medium Enterprises:A Study of Galeristorey Online Business.Etikonomi. 16(1), 115-125.https://doi.org/ 10.15408/ etk.v16i1.3950.

Sianturi, Ronda Deli. (2020).Manajemen Pemasaran Menggunakan Analisis SWOT Pada MSMe Guna Meningkatkan Daya Saing UMKM.Journal of business and Economics Research, Volume 1 No. 1, February 2020.45-50

Solihin, Ismail. (2012). Manajemen Strategik. Jakarta .Penerbit Erlangga

Sudjilah, Enny Rachmawati (2018). The effect of Brand Image and Brand Prefrences on Dicision to Buy Collection Power School Equipment Products.International Institute for Science, Technologiy \& Education. Journal of Marketing and Consumer Research.Volume 51 (2018).1-6. http://iiste.org

Sugiyono. (2014). Metode Penelitian Kuantitatif, Kualitatif, dan R\&D.: Bandung. CV Alfabeta.

Sunarti, Pratiwi Anggraeni dan M. Kholid Mawardi.(2017).Analisis SWOT Pada UMKM Keripik Tempe Amel Malang Dalam Rangka Meningkatkan Daya Saing Perusahaan. Jurnal Administrasi Bisnis (JAB)|Volume 43 (1) Februari 2017. 4-113. http://www.ub.ac.id.administrasibisnis.studentjournal ,

Suparwoko (2010). Pengembangan Ekonomi Kreatif Sebagai Penggerak Industri Pariwisata. Simposium Nasional 2010: Menuju Purworejo Dinamis dan Kreatif.p. 52-66

Syukri, Muhammad (2011). Analisis Strategi Pengembangan Sektor Usaha Mikro Kecil dan Menengah. Tesis Program Pascsarjana Universitas Terbuka. Jakarta. 
Tambunan, Tulus. (2012). Usaha Mikro Kecil dan Menengah di Indonesia.Isu-Isu Penting.Penerbit LP3S.Jakarta. Titik Inayati, Evianah, Hendra Prasetya. (2020). Perumusan Strategi Dengan Analisis Swot Pada Usaha Mikro Kecil Menengah (Studi Kasus MSMe Produk Sepatu di Mojokerto, Jawa Timur. Seminar Nasional Manajemen dan Bisnis ke-3 Program Studi Manajemen Fakultas Ekonomi dan Bisnis Universitas Jember.

Tuominen, P., \& Ascenção, M. P. (2016). The Hotel of Tomorrow. Journal of Vacation Marketing. Vol. 22(3): 279-292. doi: https://doi.org/10.1177/1356766716637102.

Undang-Undang Republik Indonesia Nomor 20 tahun 2008. Tentang Usaha Mikro Kecil Menengah dan Koperasi.

\section{Acknowledgment}

I wish to thank to my Institutions: LLDIKTI Wil. VII East Java, Yayasan Akademika Malang, the Leader and team and civitas Academica of STIE Indonesia Malang. The Head and street vendors of Malang urban Village of Bandulan who has agreed to give a research permit and respondents, my big family. I would like to give my sincere thanks for all.

I also say thank you to :

1. Indonesian College of Economics, Malang. East Java.

2. Mayjen. Sungkono University. Mojokerto, East Java.

Who has contributed a lot in writing this article. 